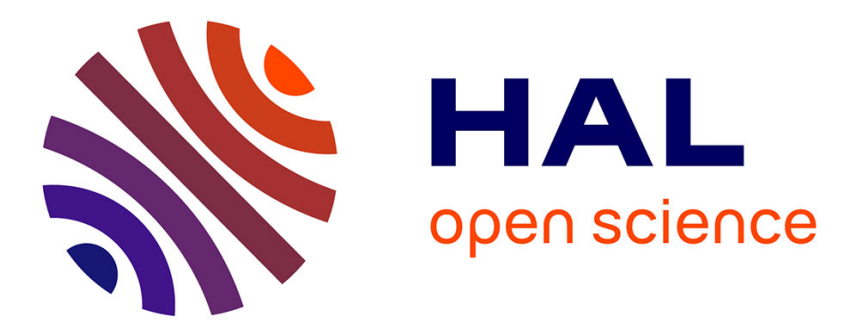

\title{
A French experience of continuous scour monitoring on real sites
}

Frédérique Larrarte, Hugues Chollet, Louis Battist, Yannick Dela Longua, Christophe Chevalier

\section{- To cite this version:}

Frédérique Larrarte, Hugues Chollet, Louis Battist, Yannick Dela Longua, Christophe Chevalier. A French experience of continuous scour monitoring on real sites. 38th IAHR World congress, International Association for Hydro-Environment Engineering and Research (IAHR), Sep 2019, Panama city, France. 7p, 10.3850/38WC092019-0410 . hal-02318393

\section{HAL Id: hal-02318393 https://hal.science/hal-02318393}

Submitted on 18 Oct 2019

HAL is a multi-disciplinary open access archive for the deposit and dissemination of scientific research documents, whether they are published or not. The documents may come from teaching and research institutions in France or abroad, or from public or private research centers.
L'archive ouverte pluridisciplinaire HAL, est destinée au dépôt et à la diffusion de documents scientifiques de niveau recherche, publiés ou non, émanant des établissements d'enseignement et de recherche français ou étrangers, des laboratoires publics ou privés. 


\title{
A FRENCH EXPERIENCE OF CONTINUOUS SCOUR MONITORING ON REAL SITES
}

\author{
FREDERIQUE LARRARTE ${ }^{(1,2)}$, HUGUES CHOLLET((3), LOUIS BATTIST ${ }^{(4)}$, YANNICK DELA LONGA $^{(5)}$ \\ CHRISTOPHE CHEVALIER ${ }^{(6)}$ \\ (1) Institut français des sciences et technologies des transports, de l'aménagement et des réseaux, Bouguenais, France, \\ frederique.larrarte@ifsttar.fr \\ (2) Laboratoire d'Hydraulique Saint Venant, Chatou, France, \\ (3) Institut français des sciences et technologies des transports, de l'aménagement et des réseaux, Marne la Vallée, France, \\ hugues.chollet@ifsttar.fr \\ (3) Institut français des sciences et technologies des transports, de l'aménagement et des réseaux, Marne la Vallée, France, \\ louis.battist@ifsttar.fr \\ (5) SNCF Réseau - Direction Générale Industrielle \& Ingénierie, Direction Zone D'ingénierie Atlantique, Limoges, France \\ (6) Institut français des sciences et technologies des transports, de l'aménagement et des réseaux, Marne la Vallée, France, \\ christophe.chevalier@ifstar.fr
}

\begin{abstract}
Controlling the risk of scouring of structures, beds or banks due to natural hazards (floods, floods, extreme hydraulic regimes, dam failures) is a major challenge for sustainable development and land use planning. These processes are the main cause of destruction of buildings (civil engineering structures, earthworks, buildings) during major floods. The SSHEAR project, "Soils, Structures and Hydraulics: Expertise and Applied Research" has been set up to improve scour mechanisms knowledge, to develop innovative experimental and observational tools and hydraulic numerical models at both laboratory and full-scale, and then to build optimized diagnostic, warning and management methods for bridges operators. This paper reports on the "field approach" task of SSHEAR project.. Among the work carried out, we have investigated whether relatively inexpensive methods using commercial sensors can be implemented. After a shot remembering of the scour parameters to be monitored, the benchmark study and the choice of monitoring devices available on the market have been detailed. The preliminary results presented here show that the challenge is being met.
\end{abstract}

Keywords: Scour, field study, monitoring

\section{INTRODUCTION}

Controlling the risk of scouring of structures, beds or banks due to natural hazards (floods, floods, extreme hydraulic regimes, dam failures) is a major challenge for sustainable development and land use planning. These processes are the main cause of destruction of buildings (civil engineering structures, earthworks, buildings) during major floods. In rail or road transportation infrastructure system, bridge maintenance represents a high operating cost. Because of their ability to connect territories and populations, any failure can have significant financial, human and social impact. In most configurations, bridges are across rivers. This flow/structure interaction leads to scouring process that represents a significant contributing factor in the deterioration of structures and could lead to collapse. For example, the French rail network has 8,000 engineering structures for river crossings, of which 1,700 are monitored for disorders related to scouring.

Financed by the French Research Agency (ANR), the SSHEAR project, "Soils, Structures and Hydraulics: Expertise and Applied Research" has been set up to improve scour mechanisms knowledge, to develop innovative experimental and observational tools and hydraulic numerical models at both laboratory and fullscale, and then to build optimized diagnostic, warning and management methods for bridges operators (Chevalier et al, 2018). This paper reports on the "field approach" task of SSHEAR project. The first step has been to identify pilot sites, representative of scour vulnerability. After a shot remembering of the scour parameters to be monitored, the benchmark study and the choice of monitoring devices available on the market will be detailed. Instrumentation, sensor adaptability, limitations (actual measurement ranges, ergonomics, energy supply limits...) and in situ implementation will then be presented and discussed. Finally, the posttreatments will be discussed as the perspectives of SSHEAR project field part. 


\section{SITE AND SET-UP SELECTION ELEMENTS}

We have tried to look at what exists in countries whose context seems similar to the French hydro-geological context, that ranges from oceanic to Mediterranean climate through mountainous one, if we limite our present study to the metropolitan area, for practical reasons.

Several criteria were defined to select the sites that would be monitored during a brief campaign and for some longer continuous periods. These criteria were related to:

- bridge vulnerability to scour,

○ bridge geometry (type of bridge and its representativeness, type of piers, ...),

- river conditions (flow conditions, hydro-morphology, nature of sediment...),

- geology and geotechnical parameters (foundations type, bedrock or reinforcement presence...),

- site accessibility,

○ staff and materials safety...

An inventory of their sites affected by scouring phenomena was carried out by the network managers (railway and highway), who are members of the partnership, using geographical information system tools and their databases. The selection has then been finalized and restricted to 3 sites:

- The Allier site corresponds to the scouring of a backfill in a meander. Such situations are common in valley bottom structures, while all infrastructures are concentrated near the river, as is the case in the mountainous regions of France. This is associated with a semi mountainous climate. It has been chosen to make precise hydraulic and bathymetric surveys once a year.

- The A71 motorway bridge over the Loire is representative of large structures crossing a river in France in an oceanic climate. This structure is based on 6 piers, 4 of which are located in the riverbed. It has been chosen to implement continuous monitoring devices.

- The railway bridge over the Aurence is a characteristic arch bridge built on the banks of watercourses. It is also in the oceanic zone. It is representative of the structures of secondary road and rail networks. It has been chosen to implement continuous monitoring devices..

In this paper we focus on this latter site that is located on the railway line linking Limoges to Angoulême in the southwest of France. Traffic consists of commuter trains and freight trains, including those from a quarry that provides ballast, particularly for bullet train lines. The bridge is a masonry rail one built about 1880 (Figure 1a). Due to the meandering course of the river, the left bank is in an extrados situation (Figure 1b). At the foot of the abutment, we measured a scour of $1.7 \mathrm{~m}$ long and $0.5 \mathrm{~m}$ deep. The pearl is collapsed and many of the blocks at the bottom of the river come from it.

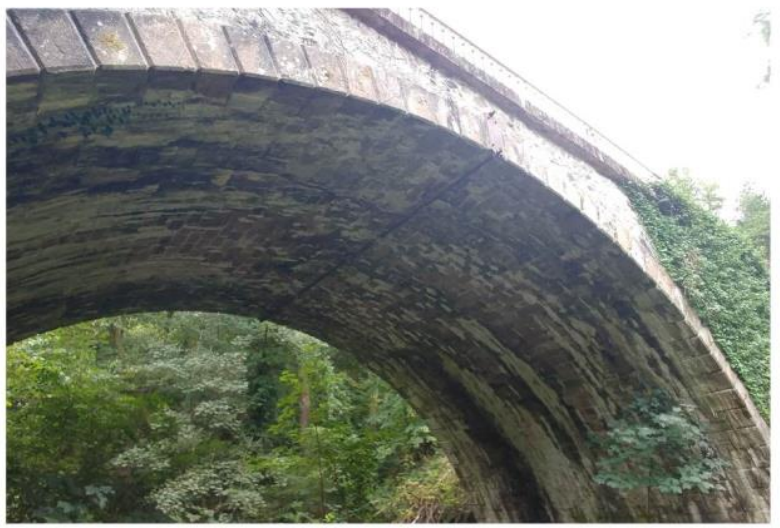

a) view of the bridge masonry

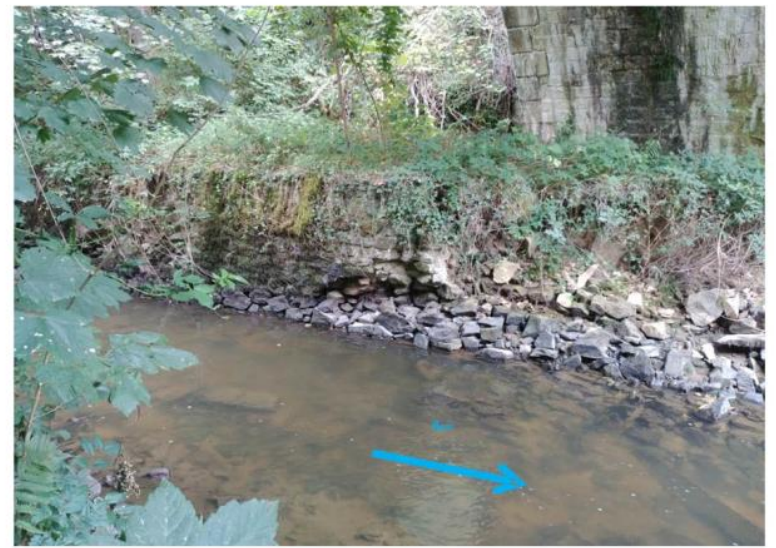

b) flow and abutment scour

Figure 1. .View of the site in August 2018

Scouring is the digging action due to eddies generated in a river or marine current encountering a natural (concave bank of meanders) or artificial obstacle (bridge pier, jetty). According to Breusers et al. (1977), equilibrium scour depth $d$ can be described by equation (1):

$$
d=f\left(\rho, v, g, D, \rho_{s}, d_{o}, U, b\right)
$$


where $\rho$ is the density; $v$ is the kinematic viscosity of the fluid, $g$ is the acceleration of gravity; $D$ is the diameter of the sand and $\rho_{s}$ its density, $d_{o}$ the depth and $U$ the velocity of the undisturbed flow, $b$ the pier diameter. There are other formulations and even very many laws, each with its own limitations, as shown by Sheppard et al (2011).

As indicated in equation (1), the essential measurands are water height, velocity and grain size. Jerez et al (2012) have reviewed the means of determining erosion, but few of those devices can be used outside the context of research work. Fischer et al (1999), Forbe et al (1999) have presented a radar technics to measure the scour depth. Hunt (2009, Fisher et al. (2013), Prendergast et Gavin (2014, Khan and Atamturktur (2015), Wang et al (2017) have presented reviews of monitoring technics. However, they focus on sour depth and mathymetric technics and they speak quite a little about the flow velocity.

While one of our purposes was also to be able to make recommendations to managers in terms of possible instrumentation, we have also chose to use as a priority commercial sensors for the monitoring of last two sites.

Taking account of the safety constrains, of the energy supply, of our budget, of the site location relatively to our laboratories location, we have decided to implement an ultrasonic water level gauge in order to measure the water level relatively to the bridge and a ultrasonic velocity profiler to measure both the water depth between the free surface and the bed of the river and the streamwise velocity profile. To identify the water level (Figure 2) and velocity ranges, we have used the closer point of the French National database Banque Hydro (http://www.hydro.eaufrance.fr/), located $1.5 \mathrm{~km}$ upstream. Figure 2 shows that on the last twelve years the water level remains below 2.5 meters and ranges from 0.5 to $1.5 \mathrm{~m}$ in most of the time. The water level gauge is an ljinus LNU06V3-82-3G ultrasonic device using the transit time principle.

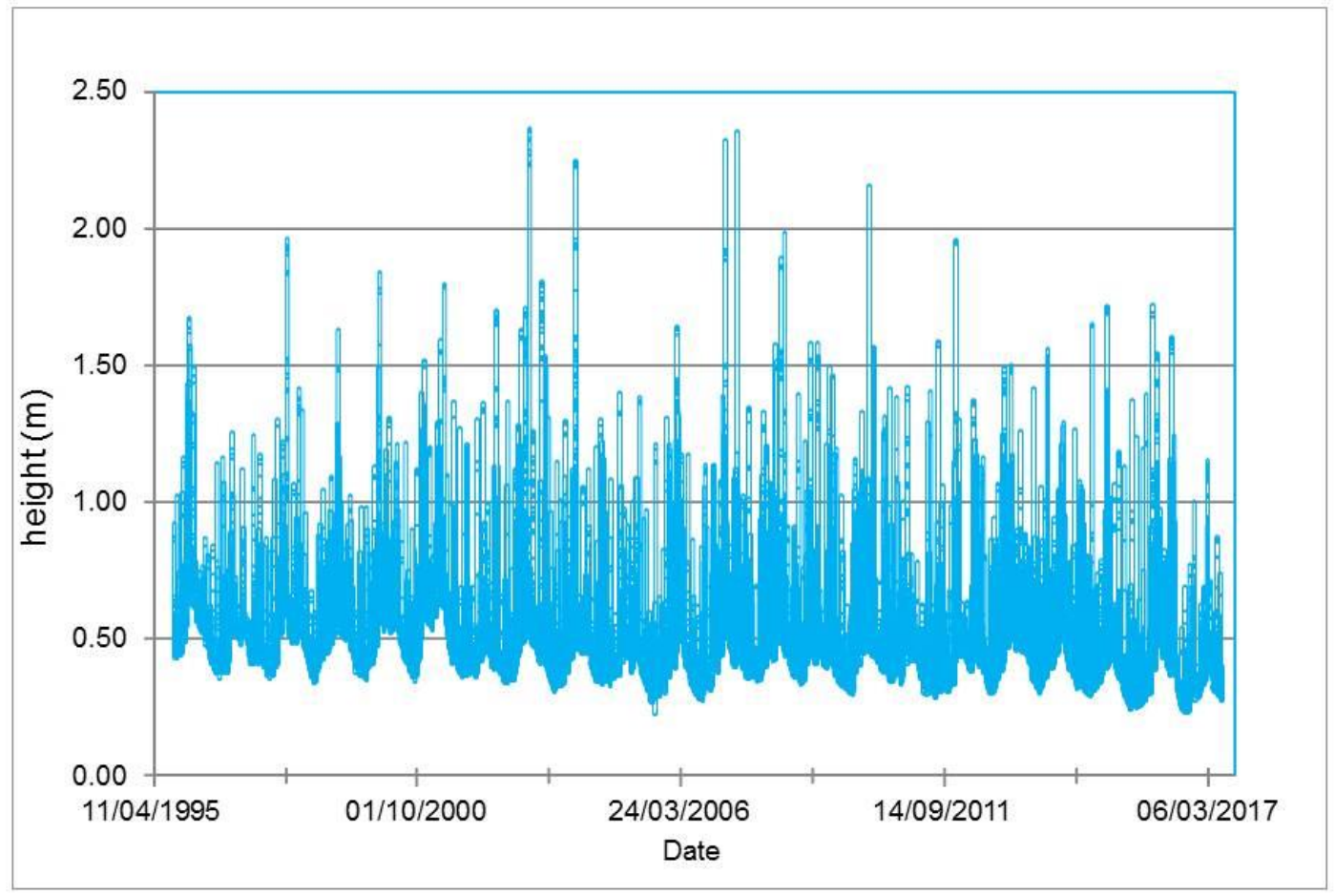

Figure 2 : Water level 12 years chronicle

The velocity profiler is an ultrasonic Ub-flow UBF156 by Ubertone (Hemmerle et al, 2014). The profiler is made to simultaneously measures the streamwise and vertical velocities. This sensor is constituted by two transducers: the first one $(\operatorname{Tr} 1)$ has an inclination angle of $65^{\circ}(\beta 1)$ with regard to the Ub-flow base and an emission frequency centered on $1.5 \mathrm{MHz}$. The second transducer $(\operatorname{Tr} 2)$ has an inclination angle of $97^{\circ}(\beta 2)$ with an emission frequency centered on $3 \mathrm{MHz}$. This sensor configuration allows to make a velocity profile with a spatial discretisation up to $5 \mathrm{~mm}$ below the dead zone that is $5 \mathrm{~cm}$ long, and a transversal resolution of 10 $\mathrm{cm}$. In order to have the profiler remaining at the free surface, it is mounted on a floating device (Figure 3). In addition, a HIK Vision 4MP WDR fixed drone network camera has been implemented to watch the sensors periodically in order to identify any emergency situation. 


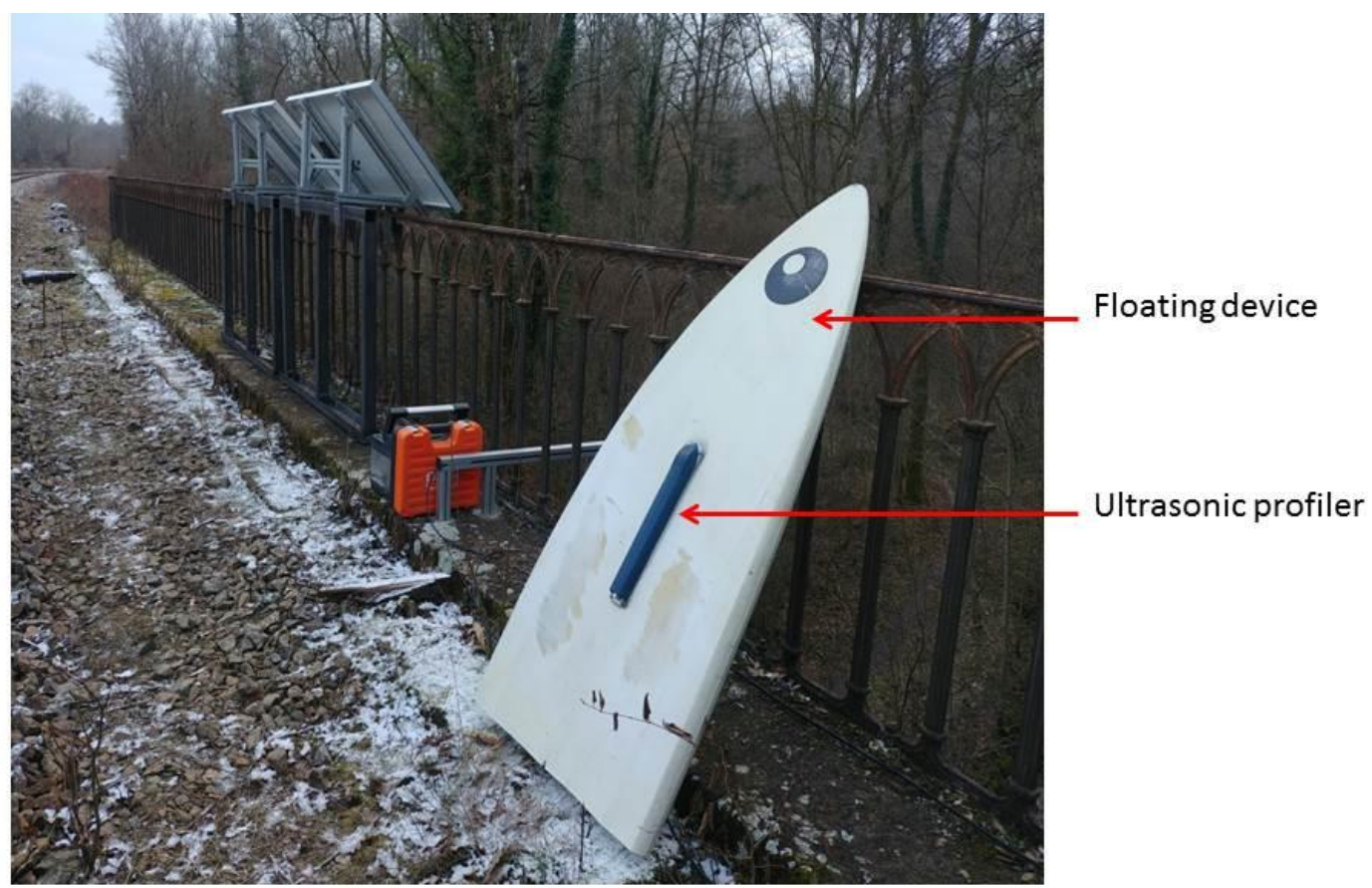

Figure 3 : View of the implementation of the profiler

Due to the location of the site is located in the countryside, both energy and data transmission by GSM network have to be provided for several months, as we plan to monitor this site for various hydraulic conditions, even during spring floods. Figure 4 shows the instrumentation scheme, the energy comes from two solar panels.

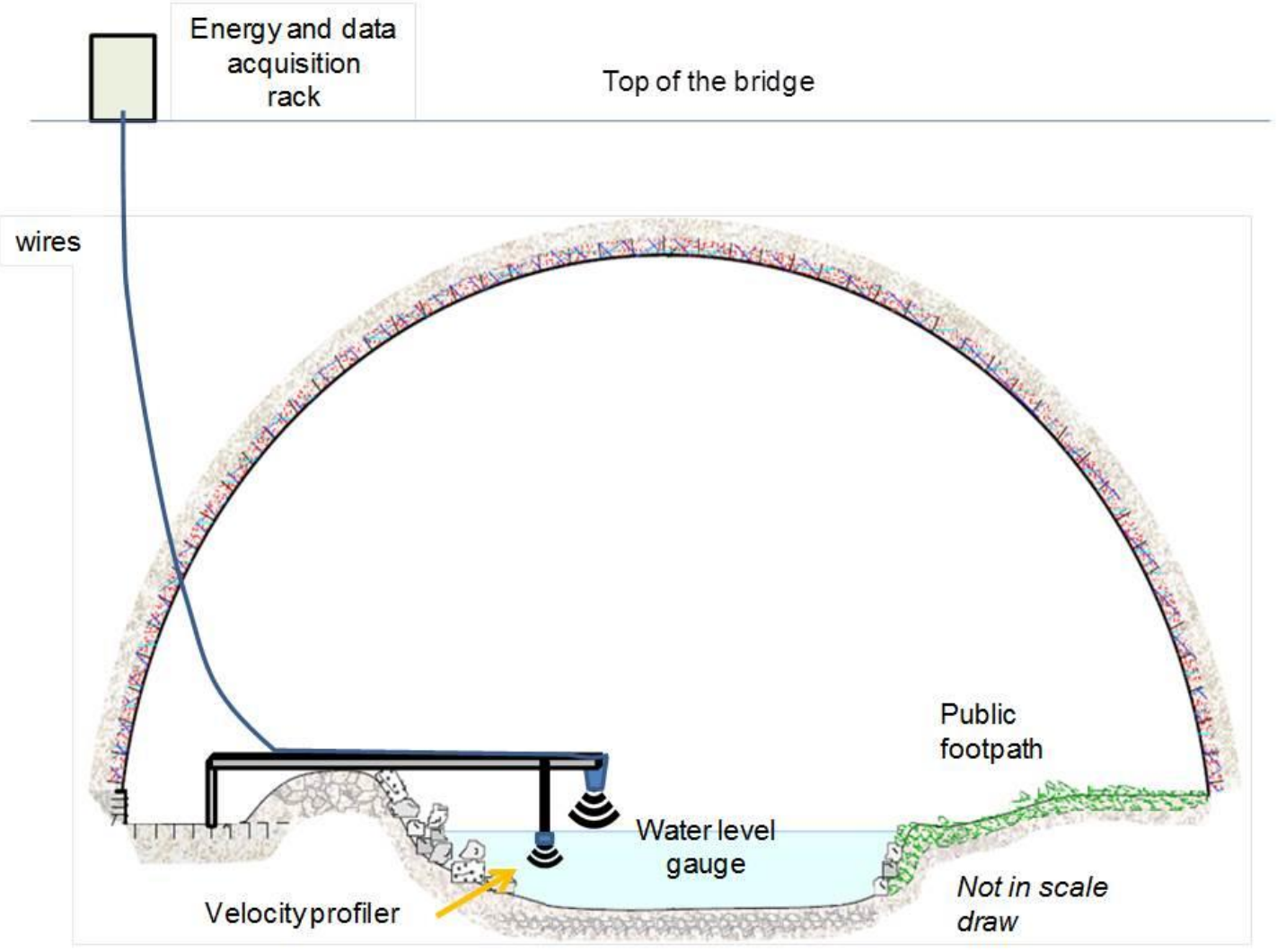

Figure 4 : Instrumentation scheme 


\section{RESULTS}

\subsection{Water levels}

The ultrasonic liminimeter records the water level every 5 minutes. We can observe small fluctuations that seem related to the natural fluctuations of a river free surface (Figure 5). Those fluctuations can easily be smoothed as presented with the mean value. It is very interesting to notice that the dynamic is the same that on the point of the Banque Hydro, even if a constant gap of $0,22 \mathrm{~m}$ can be noticed. This last point is due to different reference levels that are currently checked. Another interesting point is the great reactivity of the water level to the precipitations. Contacts are currently taken to have access to meteorological data on this area.

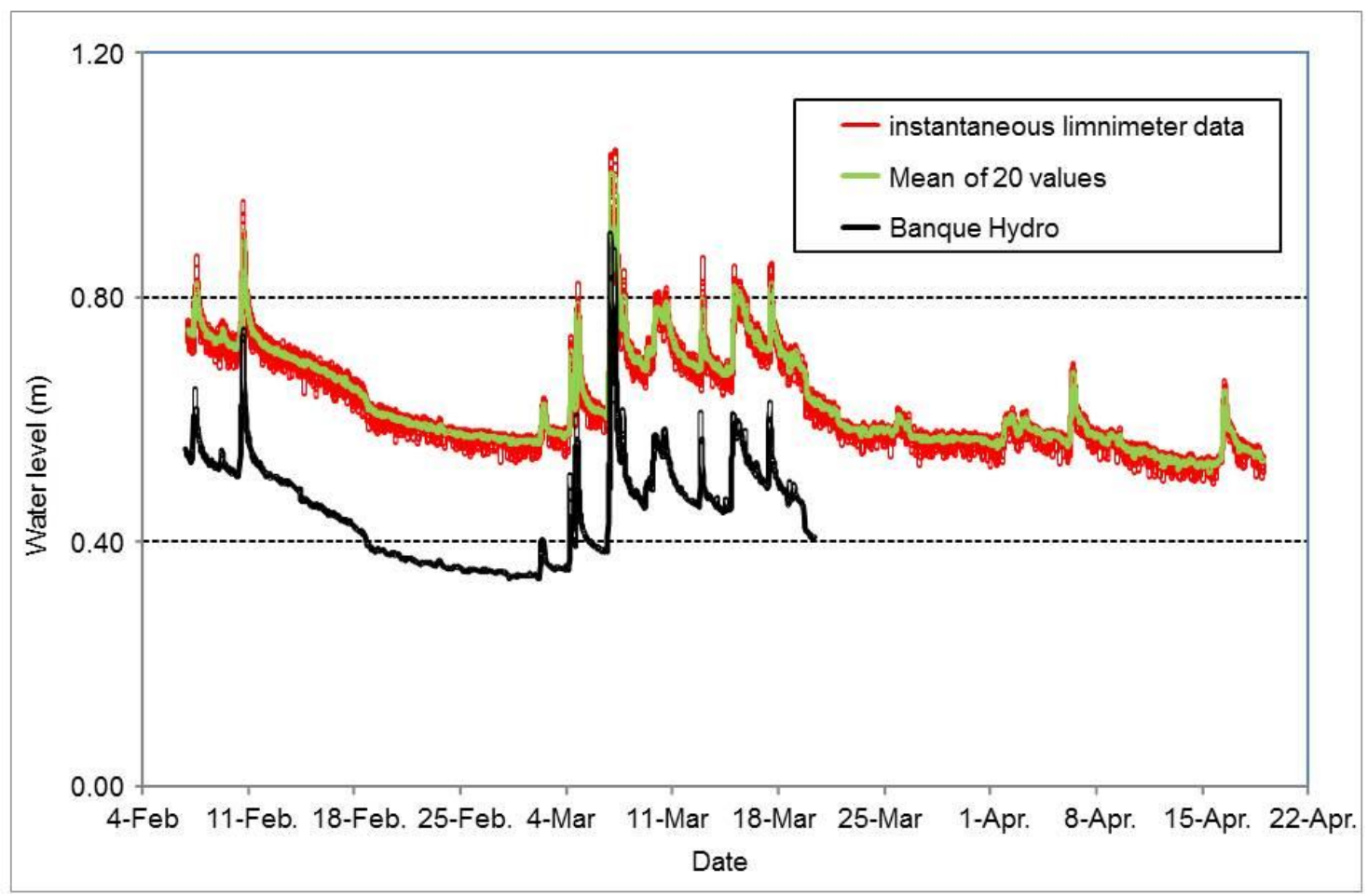

Figure 5 : Comparison of water level chronicles in 2019

\subsection{Velocity}

The ultrasonic profiler is located at the free surface to prevent any interaction with the river bed as we work on scour that is among the erosion processes family. Thus the first point is to be able to identify were this bed is. The sensor is rather complex to handle and the configuration need to be validated. However, an important point is that the backscattered signal amplitude allows us to locate this bed, as proposed by Hemmerle et al (2014). Figure 6 shows an example of the amplitude profile. For this case, a strong peak can be seen at a distance of $0.73 \mathrm{~m}$ from the sensor.

Thus the vertical velocity distribution can be presented in an usual way as on Figure 7 . The velocity profile presents fluctuations that are consistent with real site measurements. In the inner region, a logarithmic law can be fitted (equation (2) that allows evaluating the roughness and the shear velocity:

$$
\frac{u_{x}(z)}{u_{*}}=\frac{1}{k} \ln \left(\frac{z}{k_{s}}\right)+B_{s}
$$

where $u_{x}(z)$ is the streamwise velocity measured at a distance $z$ from the bottom, $h$ the water level, $u^{*}$ the shear velocity, $\mathrm{K}$ the von Karman constant equal to $0.4, \mathrm{k}_{\mathrm{s}}$ the equivalent sand grain roughness and $\mathrm{B}_{\mathrm{s}}$ the integration coefficient equal to 8.5 . 


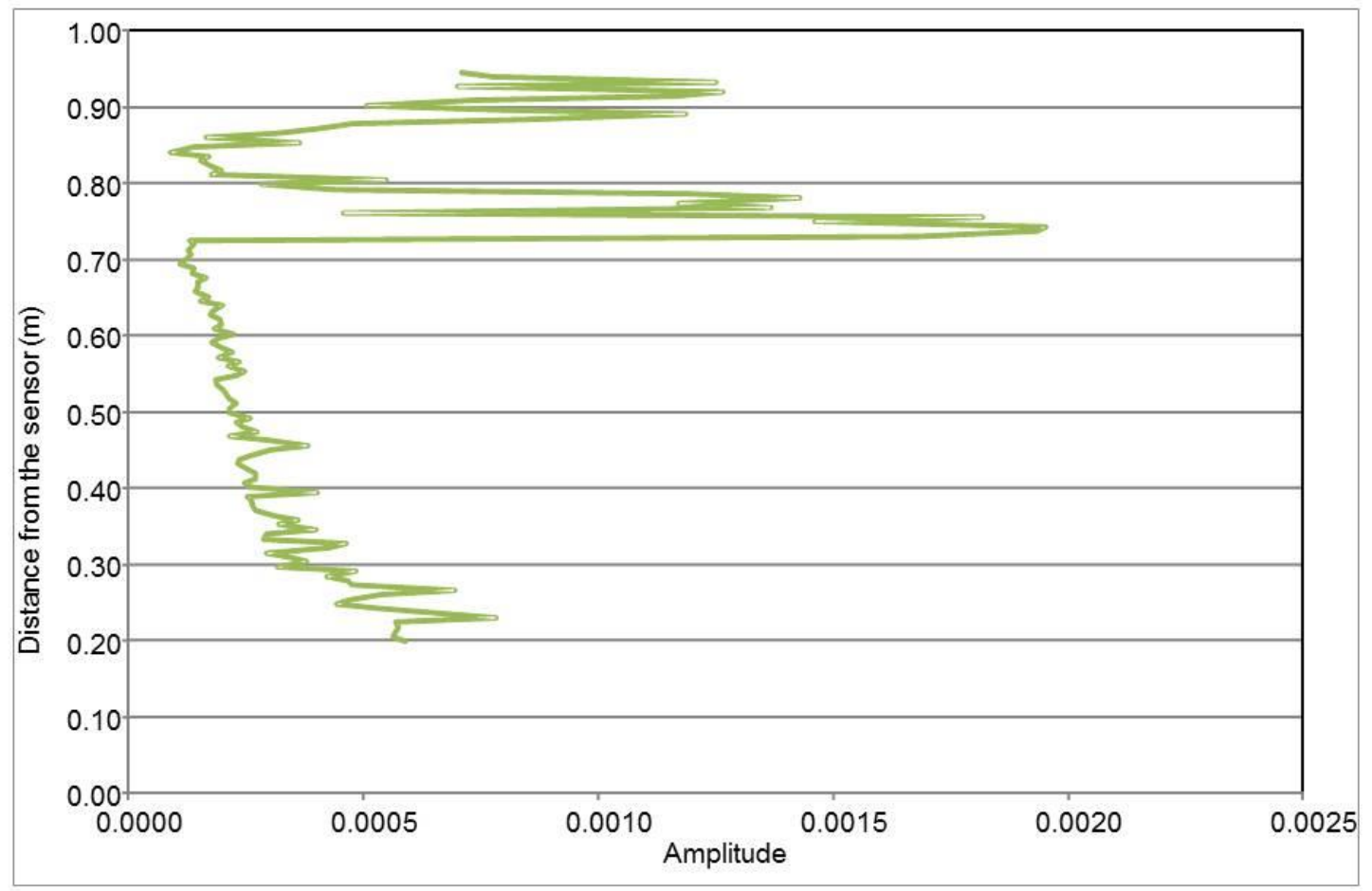

Figure 6 : Backscattered signal amplitude profile

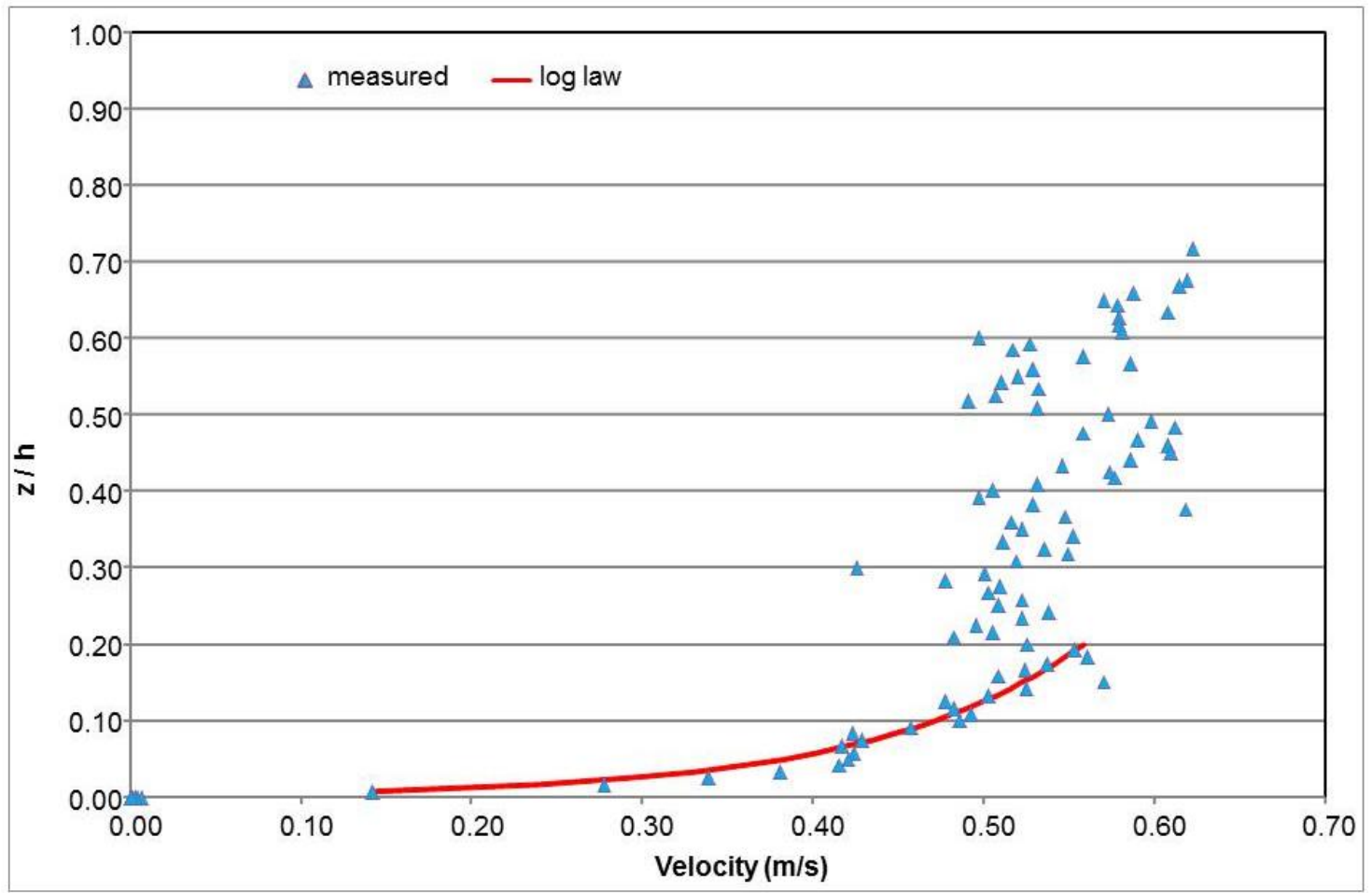

Figure 7 : Vertical velocity profile and logarithmic law in the inner region

\section{CONCLUSIONS}

Scouring is a major risk for civil engineering structures and monitoring of its structures could help prevent major failures. Among the work carried out, we have investigated whether relatively inexpensive methods using commercial sensors can be implemented. After a shot remembering of the scour parameters to be monitored, the benchmark study and the choice of monitoring devices available on the market have been detailed. The preliminary results presented here show that the challenge is being met. 


\section{ACKNOWLEDGEMENTS}

The present work benefits from the financial support of the ANR French Research Agency within the project SSHEAR ANR-2014-CE03-0011.

The authors thank Carlos Minatchy, Fabien Szymkiewicz of IFSTTAR Marne la Vallée (France) for their contribution to the in situ interventions, the master student Anita Ditsingouli who contributes to the data analysis process, SNCF Réseau staff in Limoges (France) for their safety and technical support, the laboratory Saint Venant in Chatou (France) for providing channels to conduct sensors testing.

\section{REFERENCES}

Breusers, H. N. C., Nicollet G., Shen H.W. (1977). Local Scour Around Cylindrical Piers. J. Hyd. Res., 15 (3): 211-252

Chevalier, C., Larrarte, F., Schmidt, F., Pham-Van-Bang, D., Durand, E., Gondret, P., de la Roque, S., Cheetham, M. \& Hosseingholian, M. (2018). Research program SSHEAR: recent advances on the understanding and the control of scour phenomena. Ninth International Conference on Scour and Erosion (ICSE), Nov. 5-8, Taipei, Taiwan.

Fisher M., Chowdhury M., Khan A., Atamturktur S. (2013). An evaluation of scour measurement devices. Flow Meas. Instrum. 33: 55-67

Forbe M.C., McCann D. M., Clark M. R., Broughton K.J., Fenning P.J., Brown A. (1999). Radar measurement of bridge scour, NDT\&E International 32, 481-492.

Hemmerle N., Randrianarimanana J.J., Joannis C., Larrarte F. 2014. Hydraulics and deposit evolution in sewers. Int. Symp. on Ultrasonic Doppler Methods for Fluid Mech. and Fluid Eng.-9. 9-12

Hunt, (2009), Monitoring scour critical bridges, A synthesis of highway Practice, NCHRP Synthesis 396

Jerez A., Chevalier C., Larrarte F. (2012). Erosion measurement on immersed situations: a state of the art, Proceedings of the Sixth International Conference on Scour and Erosion, Paris, France, Aug. 2012, pp. 687694.

Khan A.A, Huriye S. Atamturktur H.S. (2015); Real time measurement of scour depths around bridge piers and abutments, Final Report, Report No. FHWA-SC-14-05 HEC20

Prendergast L.J., Gavin K. (2014). A review of bridge scour monitoring techniques. J. Rock Mech. Geotech. Eng. 6(2): 138-149

Sheppard, D. M., Demir, H., and Melville, B. (2011). "Scour at wide piers and long skewed piers." National Cooperative Highway Research Program Rep. 682, Transportation Research Board, Washington, DC.

Wang C., Yu X, Liang F. (2017), A review of bridge scour : mechanism, estimation, monitoring and countermeasures, Nat. Hazards, 87:1881-1906 